\title{
Study the Behaviour of Underground Oil Cavern under Static Loading Condition
}

\author{
K. V. Chimmani • R. D. Lokhande $\mathbb{1}$
}

Received: 22 March 2021 / Accepted: 21 June 2021 / Published online: 21 July 2021

(C) The Author(s), under exclusive licence to Springer Nature Switzerland AG 2021

\begin{abstract}
The country's population is increasing rapidly and the need to make lives easier daily. Some of the essential needs for this generation are crude oil and electricity. India, unfortunately, does not possess any oil reserves to meet the needs of the country's demands. So, India is importing oil from other countries. Whenever there are situations like war, pandemic (COVID-19), and other emergencies, the natural oil reserved countries cannot export the oil to other countries which will lead to great chaos in the country. To avoid this situation storing the crude oil is necessary. Building surface giant structures for storing the oil is difficult and won't be economical. So, India is constructing giant underground structures called caverns, which will reserve the oil. The present study is focused on the stability of the underground cavern structure and understanding the importance of the water-curtaining system. To analyse the stresses and displacement 2D modelling has been done. In this, wet and dry models are prepared and analysed based on the available geological and geotechnical data to
\end{abstract}

We hereby declare that this submission is our work and that to the best of our knowledge and belief. This research work is done on the Master's degree of the first author.

K. V. Chimmani · R. D. Lokhande ( $\square)$ Department of Mining Engineering, VNIT Nagpur, Nagpur, Maharashtra, India

e-mail: riteshlokhande@gmail.com determine the stresses around the cavern and the displacement which will reach the surface due to excavation.

Keywords Stresses - Displacements - Water curtaining system

\section{Introduction}

In the current Scenario, the population is increasing rapidly and the need to make lives easier in day-to-day life. Some of the needs for this computer generation are electricity, petrol, and diesel. Crude oil became an essential source to almost every household in the world. The country's economy is also dependent on these essential commodities. Not every country is fortunate enough to have these essential commodities. So, most of the countries are dependent on the oil reserved countries such as Brazil, Saudi Arabia, United Arab Emirates, Gulf countries, Russia, and other countries. In other words, the countries which possess the oil reservoirs will fix the price of the crude oil and it directly affects the Gross domestic product (GDP) of those countries which doesn't possess the fortune. Even when there are conflicts between two nations, the oil reservoirs will play a prominent role. Every country should possess at least some oil 
reserves so that it is not completely dependent on the oil reserved nations.

India's population is nearly 1.3 billion and these numbers are increasing daily. Around $70-80 \%$ of the population is completely dependent on petrol, diesel and other required needs. India doesn't possess any kind of natural oil reserves. It is completely dependent on the oil reserved nations like United Arab Emirates, Brazil, Iran, etc. Whenever there are situations like war, pandemic (COVID-19), and other emergencies, the natural oil reserved countries cannot export the oil to other countries which will lead to great chaos in the country. To eliminate these problems, India is planning to reserve the oil for emergency purposes (HöferÖllinger et al. 2014 and Mohanty et al. 2018). For storing the oil on the surface, Giant structures with impenetrable walls are required, even the smallest hole can lead to the destruction of the giant structures. With advanced technology, no doubt one can construct giant structures with airtight capacity. The main problem with giant structures is the cost. These structures are too expensive. By storing the oil on the surface will ultimately lead to an increase in the cost of crude oil which is not appreciable. The other option left is underground. The Underground is the best option for storing the crude oil because here giant structures are not needed, the only thing which is important in storing the crude oil is to maintain pressure around the stored area. For storing materials, excavation is carried at a depth generally ranging from 40 to $50 \mathrm{~m}$ from the surface and the minimum height and width of the excavation are $20 \mathrm{~m}$ and $10 \mathrm{~m}$ respectively. These excavations are termed caverns. These are used for different types of purposes such as storing food, crude oil, electricity generation, military purposes, storing of explosives, etc.

\subsection{Essential Conditions and Background}

\subsubsection{Essential Conditions}

When the cavern is closed, the gas will be left in the cavern, above the crude oil and under the maximum operating pressure of $2 \mathrm{~kg} / \mathrm{cm}^{2}$. To prevent the gas from leaking out of the cavern, a water curtain system with water pressure of $2 \mathrm{~kg} / \mathrm{cm}^{2}$ is to be adopted for both the construction period and operation period of the cavern [Lee et al. 1996]. The proper function of oil storage in underground caverns relies on the following three conditions: (1) The specific gravity of the oil must be less than that of water. (2) The oil is antidecomposition and insoluble in water. (3) The groundwater pressure around the caverns must be higher than the stored oil pressure [Wang et.al. 2015]. The water-sealing effect and rock mass stability are two key problems for the construction of underground storage caverns [Jie et.al. 2018].

\subsubsection{Background}

Cavern is derived from the word Caves which means the left-out space or area in the underground due to the geology. So, the cavern is the word used for the structure or space left out in the underground naturally or man-made. These caverns are generally used for storing materials like food grains, crude oil, military ammunition, compressed air energy, etc. Storing these materials in the surface structures won't be economically efficient. This study deals with the storing of crude oil in the cavern. Construction of the cavern is based on the Heading and Benching method. The Geology and the height of the cavern decide the number of benches in excavating the cavern. The excavation of the cavern is being carried out by the Drilling and Blasting method. For maximum efficiency, the same crew for drilling, hauling, scaling team, and charging were used to excavate at several tunnel faces. This helps in constructing the cavern in minimum time.

When the cavern is filled with crude oil after its construction, there are some gases leftovers in the cavern due to the crude oil. As the hardest rocks are impermeable, but there are at least $5-10 \%$ of the pores available in almost all rocks including hard rocks. The gases inside the cavern try to escape from the cavern through pores of the rock when the crude oil pressure is higher, this results in the propagation of cracks and at last leading to form joints or spacing between the rocks. This phenomenon damages the cavern stability leading to failure of the cavern. To restrict the abovementioned problem, a water-curtaining system is developed around the cavern in such a way that the groundwater pressure around the cavern exceeds the gas pressure inside the cavern and the trapped gases in the cavern should not escape.

The water curtaining system has been extensively used around the world for storage cavern. The water curtaining system includes the series of water curtain 
Table 1 Physical properties used in the model

\begin{tabular}{lllllll}
\hline Lithology & \multicolumn{2}{l}{ Physical properties } & & & \\
\cline { 2 - 6 } & $\begin{array}{l}\text { Dry Density, } \\
\mathrm{kg} / \mathrm{m}^{3}\end{array}$ & $\begin{array}{l}\text { Wet density, } \\
\mathrm{kg} / \mathrm{m}^{3}\end{array}$ & $\begin{array}{l}\text { Specific } \\
\text { gravity }\end{array}$ & $\begin{array}{l}\text { Porosity } \\
(\%)\end{array}$ & $\begin{array}{l}\text { Absorption } \\
(\%)\end{array}$ & $\begin{array}{l}\text { P-wave velocity, } \\
(\mathrm{m} / \mathrm{sec})\end{array}$ \\
\hline $\begin{array}{l}\text { Granitic Gneiss, medium to Coarse } \\
\text { grained, slightly weathered }\end{array}$ & 2747 & 2751 & 2.75 & 0.4 & 0.14 & 5163 \\
\hline
\end{tabular}

Table 2 Geo-mechanical properties used in the model

\begin{tabular}{|c|c|c|c|c|c|c|c|}
\hline \multirow[t]{3}{*}{ Lithology } & \multicolumn{7}{|c|}{ Geo-mechanical properties } \\
\hline & \multicolumn{2}{|c|}{$\begin{array}{l}\text { Compressive } \\
\text { strength, } \\
\mathrm{MPa}\end{array}$} & \multirow[t]{2}{*}{$\begin{array}{l}\text { Elastic } \\
\text { modulus, GPa } \\
\text { (dry) }\end{array}$} & \multirow[t]{2}{*}{$\begin{array}{l}\text { Poisson's } \\
\text { ratio (dry) }\end{array}$} & \multirow[t]{2}{*}{$\begin{array}{l}\text { Tensile Strength, } \\
\mathrm{MPa} \text {, (dry) }\end{array}$} & \multicolumn{2}{|c|}{$\begin{array}{l}\text { Triaxial compression } \\
\text { test (saturated) }\end{array}$} \\
\hline & Dry & Wet & & & & $\begin{array}{l}\text { Cohesion, } \\
\mathrm{MPa}\end{array}$ & $\begin{array}{l}\text { Friction } \\
\text { angle, }\left({ }^{\circ}\right)\end{array}$ \\
\hline $\begin{array}{l}\text { Granitic gneiss, medium to coarse } \\
\text { grained, slightly weathered }\end{array}$ & 146 & 120 & 57 & 0.23 & 12.25 & 40 & 50 \\
\hline
\end{tabular}

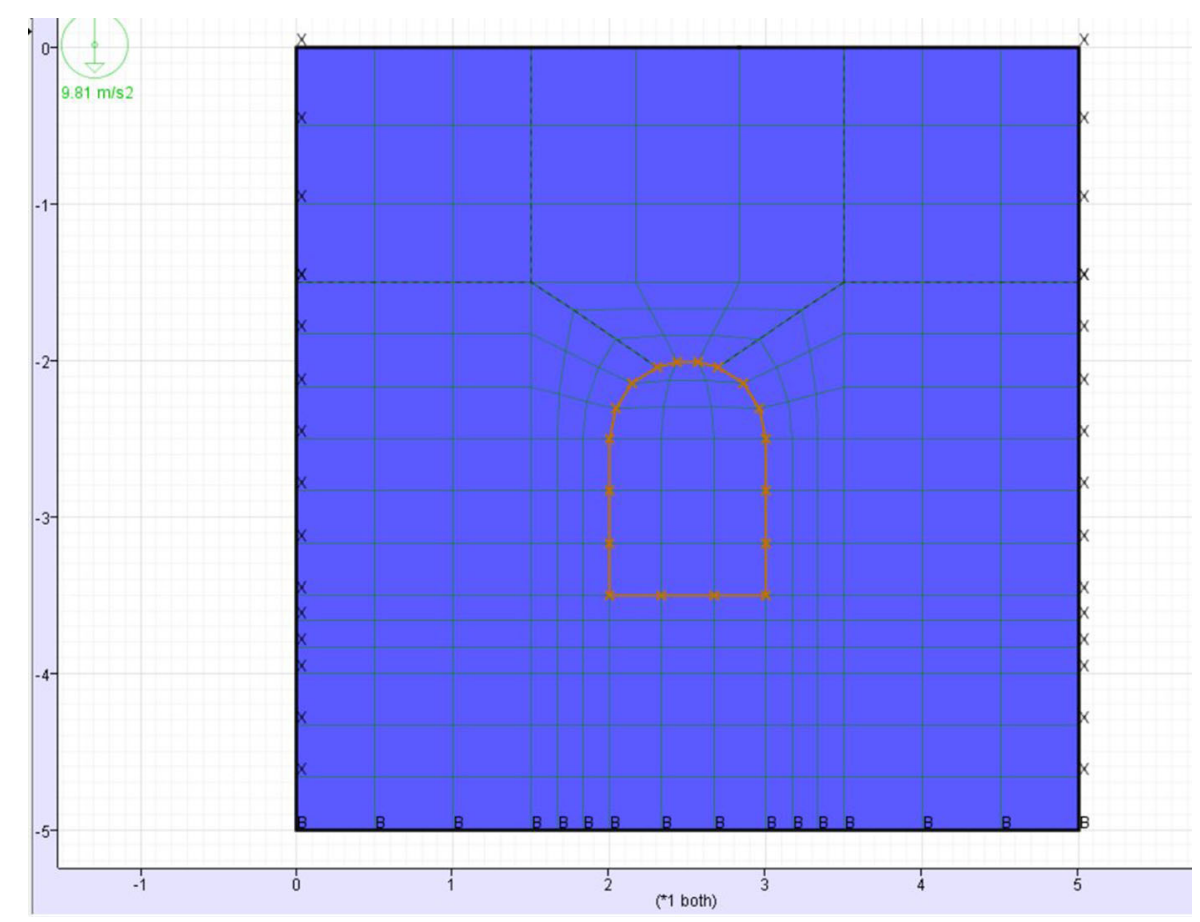

Fig. 1 Model before excavating cavern 


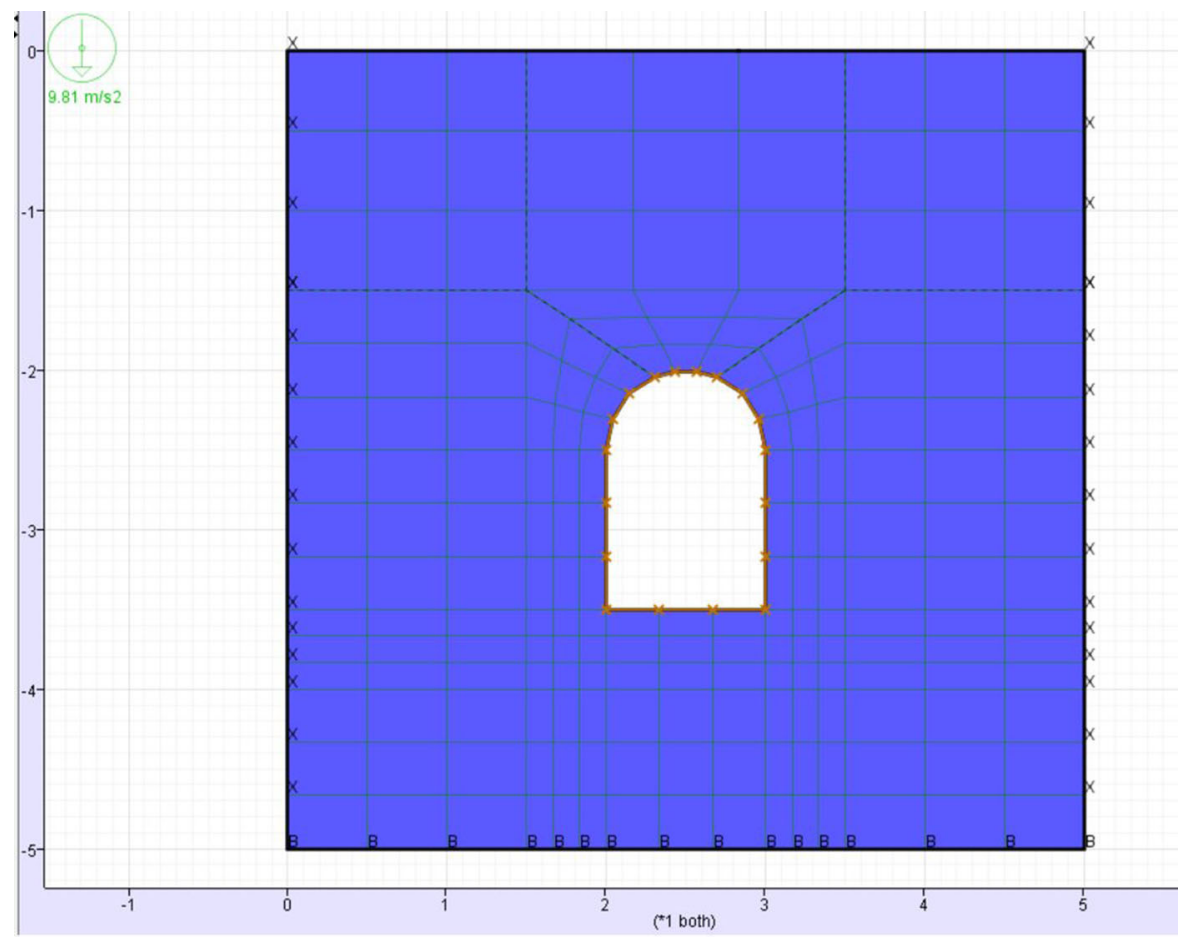

Fig. 2 Model after excavating cavern

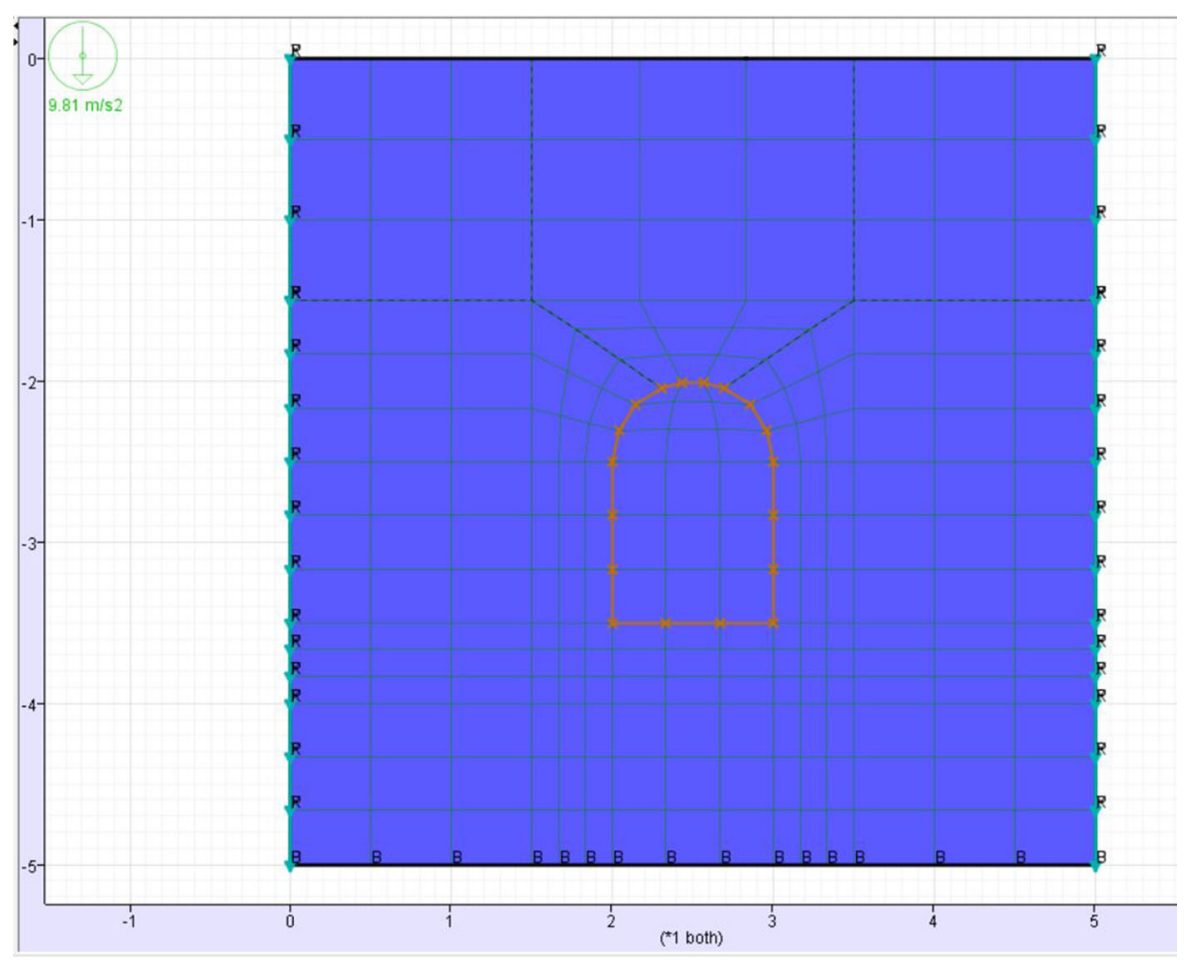

Fig. 3 Model before excavating cavern 


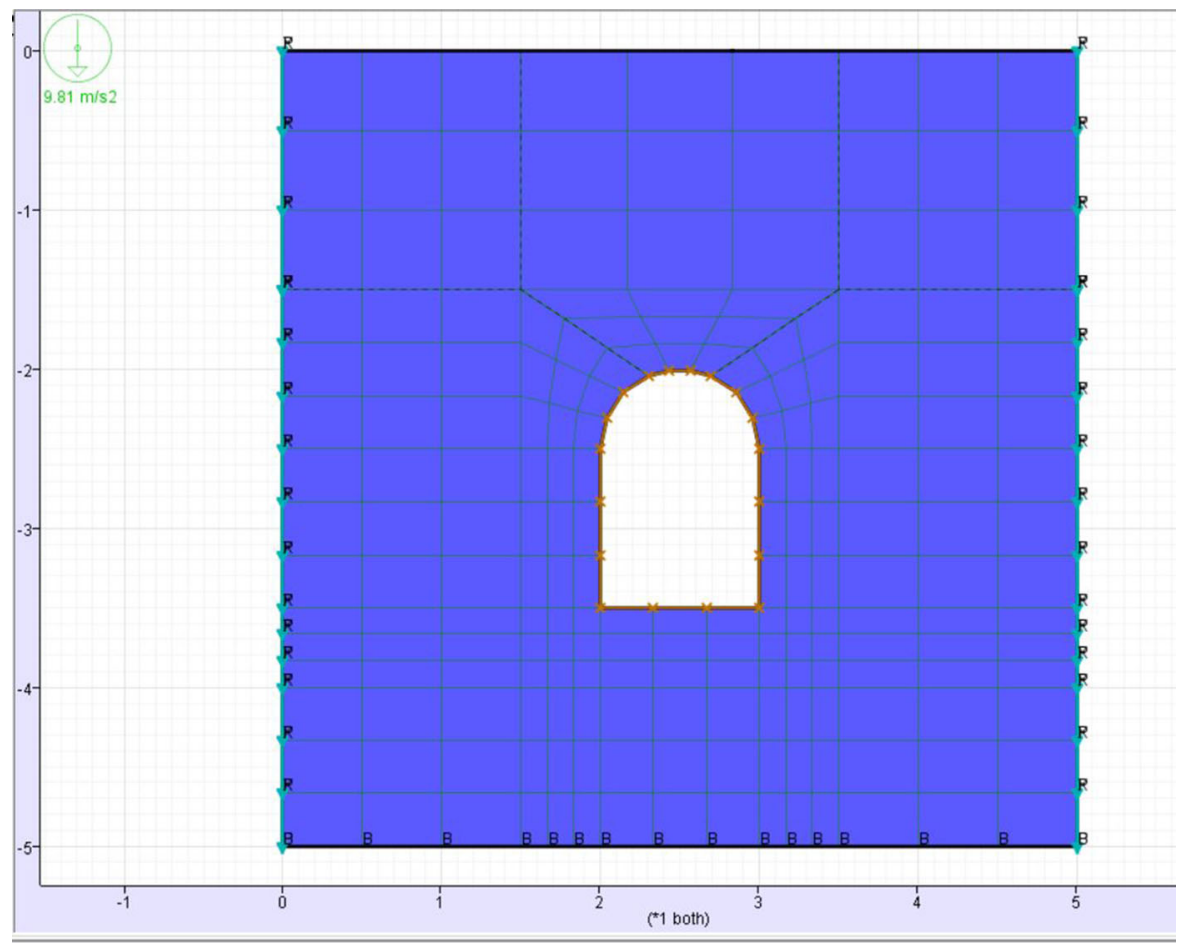

Fig. 4 Model after excavating cavern

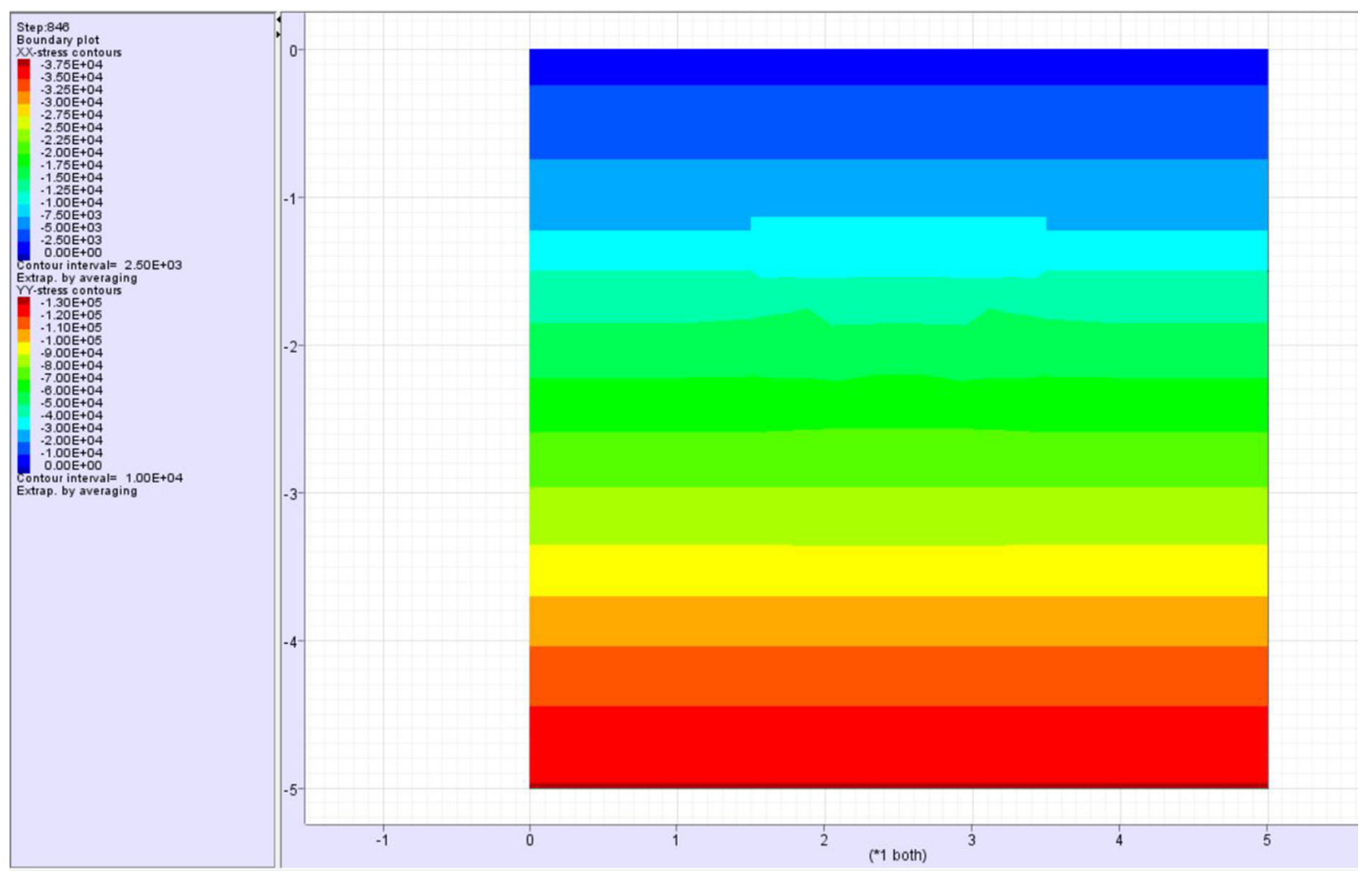

Fig. 5 Shear stress for model before excavating cavern 


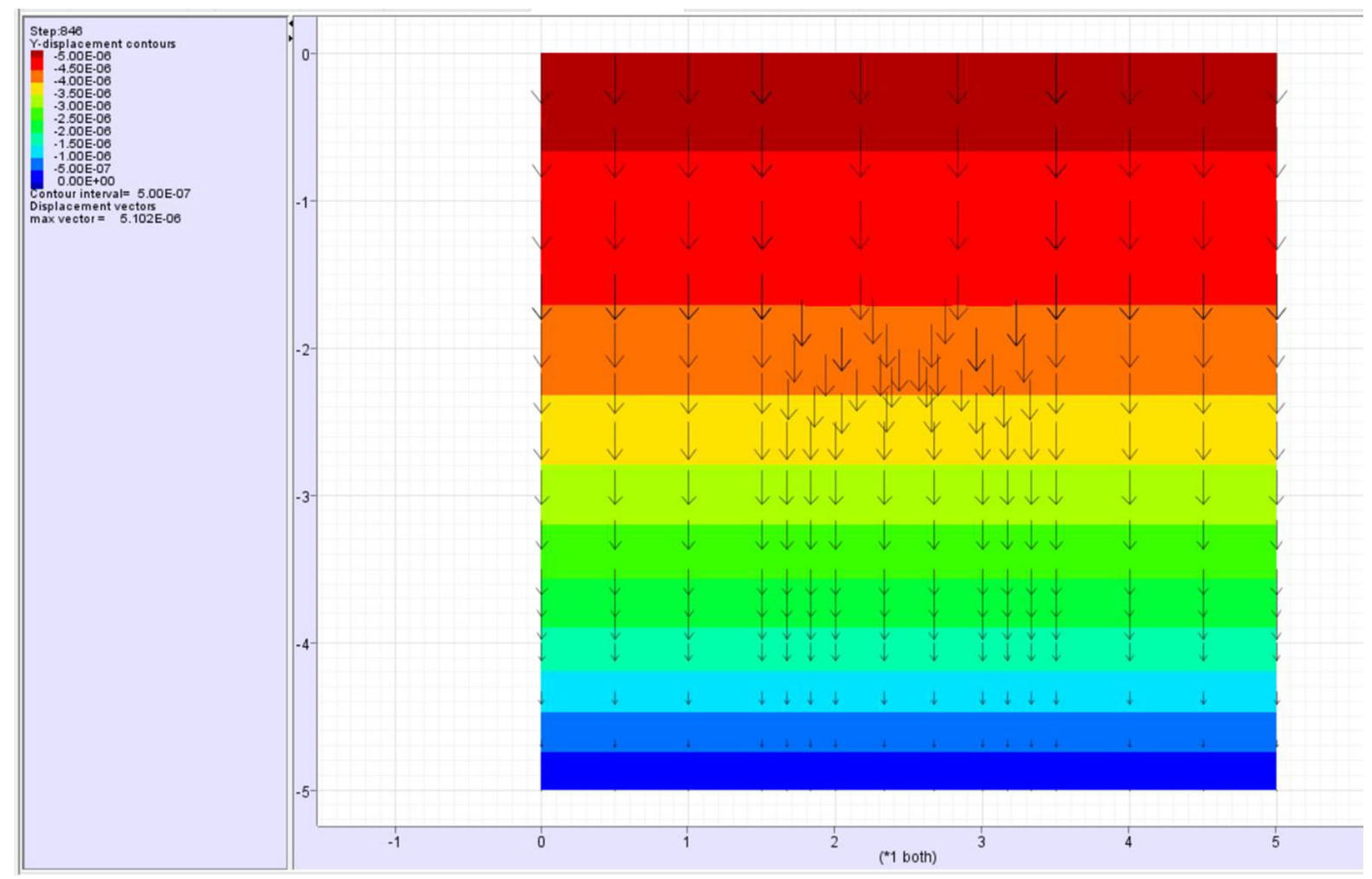

Fig. 6 Y-displacement for model before excavating cavern

tunnels and boreholes depending on the size of the cavern and oil Pressure which are placed at regular intervals over the roof of cavern or the sidewalls, if necessary (Prasanna et al. 2014). The design of the water-curtaining tunnels and the size of the boreholes also depend on the geological and Geotechnical Properties of the bedrock. The water curtaining system is generally developed $15-20 \mathrm{~m}$ above the crown of the cavern. This system is constructed before the excavation of the cavern, if the system is constructed after the excavation of the cavern, then the chances are high, that water may percolate in the cavern making it unstable. The water curtaining system is to make the continuous flow of water over the unlined storage caverns to maintain groundwater pressure, which can be altered according to the need ( $\mathrm{Li}$ et al. 2009).

With this system, the pores of the rocks are filled with water and the trapped gases cannot be able to escape from the cavern. When the Pores of the rock or the strata are filled with water, the pore pressure will be higher compared to its natural state. But it will not be higher than the permissible Pressures because these pressures can be altered or regulated using watercurtaining system pressures. The main purpose of these pore pressure is to develop a blocking space for the oil and gases in the cavern. And the water pressure in the water-curtaining tunnels and boreholes is in such a way that it should be greater than the pressure of 


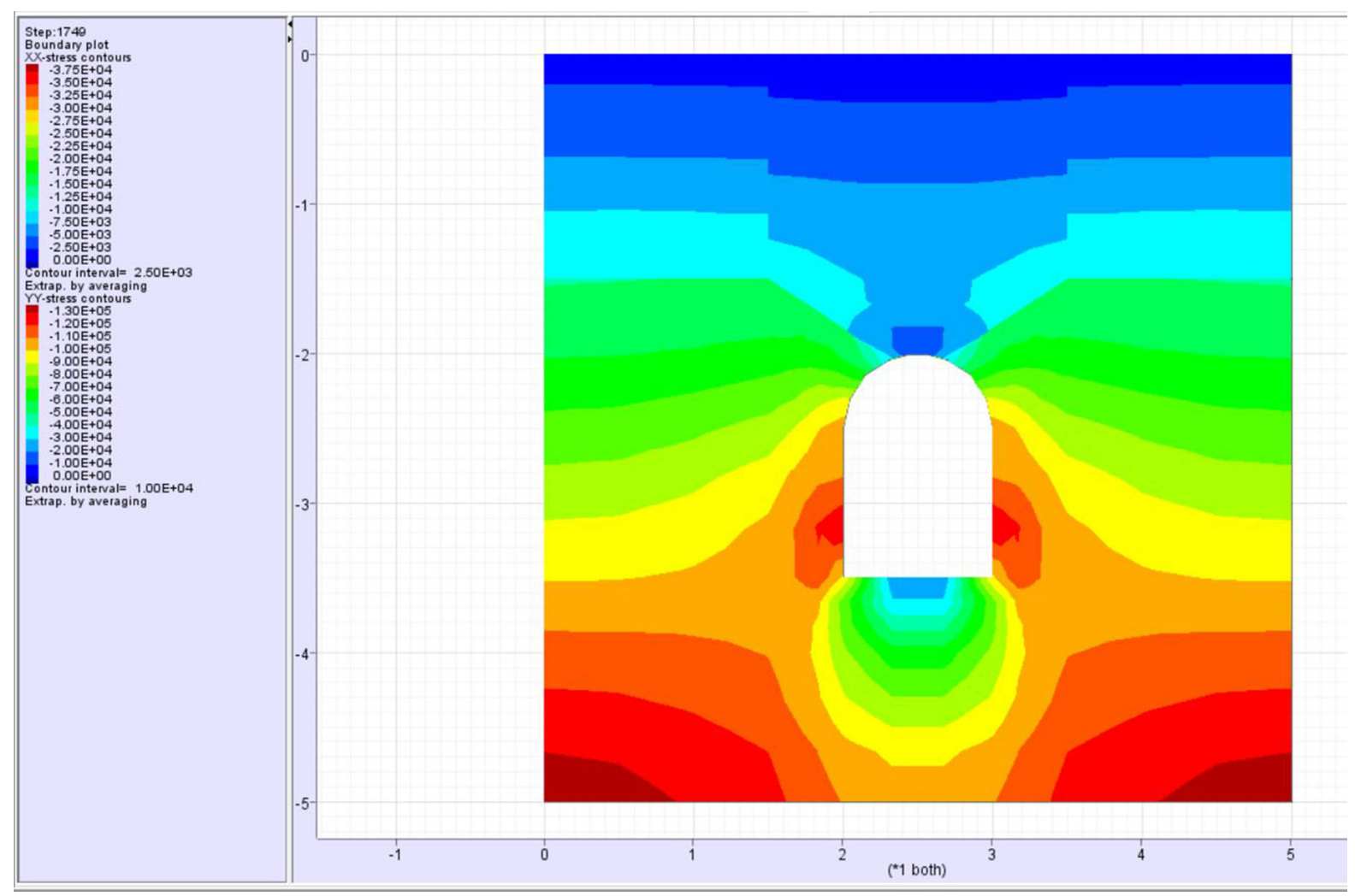

Fig. 7 Shear stress for model after excavating cavern

the crude oil inside the cavern making the entire structure a hydrodynamic containment leading to a stable structure and economically efficient.

\section{Model Development}

The models are developed using FLAC 8.0 Software which is based on the explicit finite difference method. Here two models are developed. (a) Dry state and (b) Wet State. The importance of developing Dry state model is to determine the stresses and displacement around the cavern in the absence of a water curtaining system (Lin et al. 2016). And also, to show the significance of the water curtaining system and its effects on the stresses and Displacement of the cavern.

\subsection{Properties used in the Model}

To analyse the stresses and displacement that occurred, 2D modelling has been done. The Physical and Geo-mechanical properties used to develop the model are given in Table 1 and Table 2 repectively: 


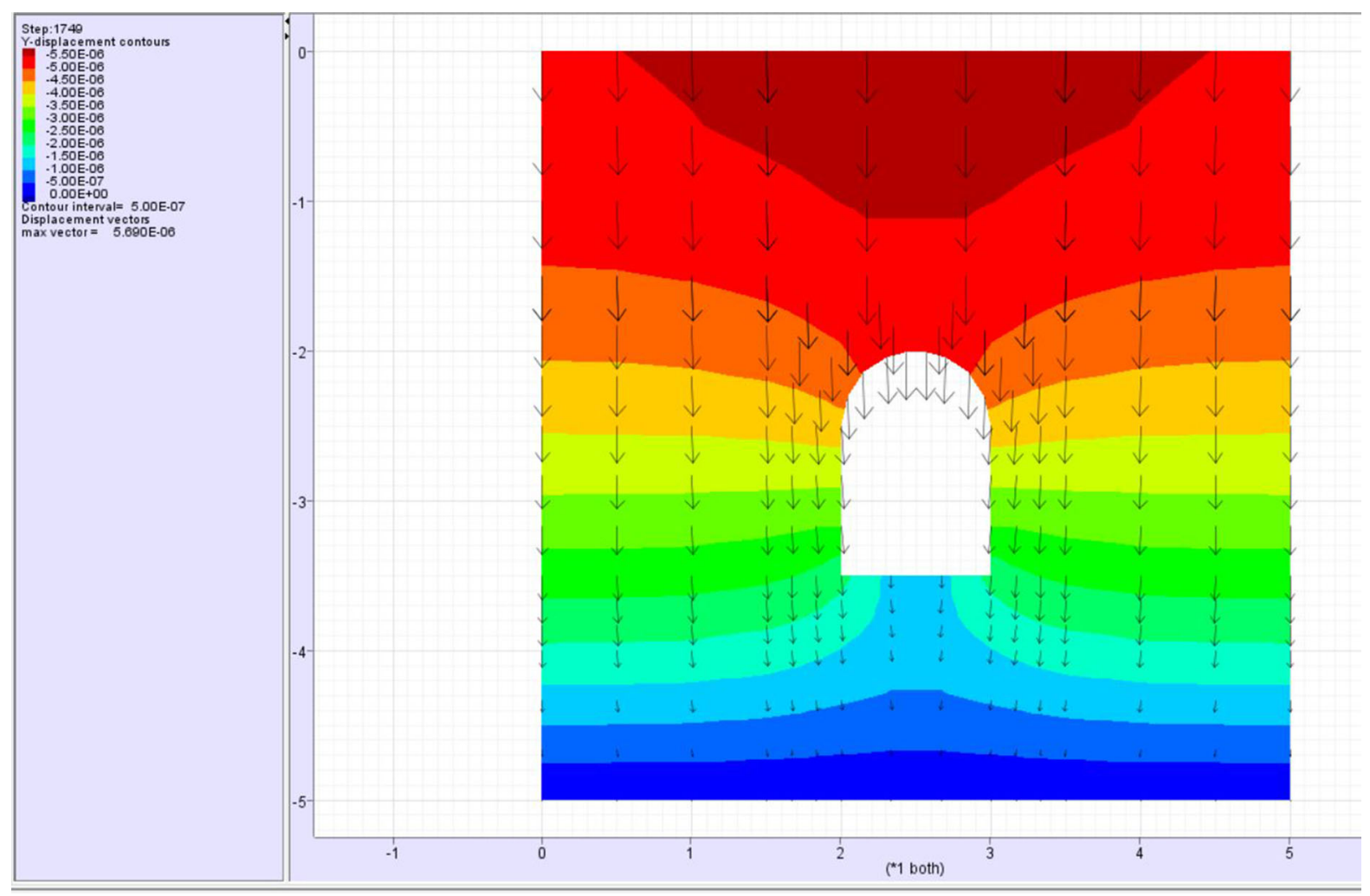

Fig. 8 Y-displacement for model after excavating cavern

\subsection{Dry State}

The above Fig. 1 model is developed using FLAC 2D Software. A single cavern is modelled along with its boundaries. No additional Stress or load is applied to the model to replicate its natural state. This model is generated to use the initial stress state condition of the strata in their virgin state.

The above Fig. 2 model is developed to indicate the cavern after its excavation in its natural state. The Dry state model is used to determine the stresses and displacement around the cavern in the absence of a water curtaining system.

\subsection{Wet State}

In Fig. 3 model is developed to represent the strata with the application of the pore pressure along the boundaries of the cavern. This pore pressure application will represent the water-curtaining system. This model is generated to use the initial stress state 


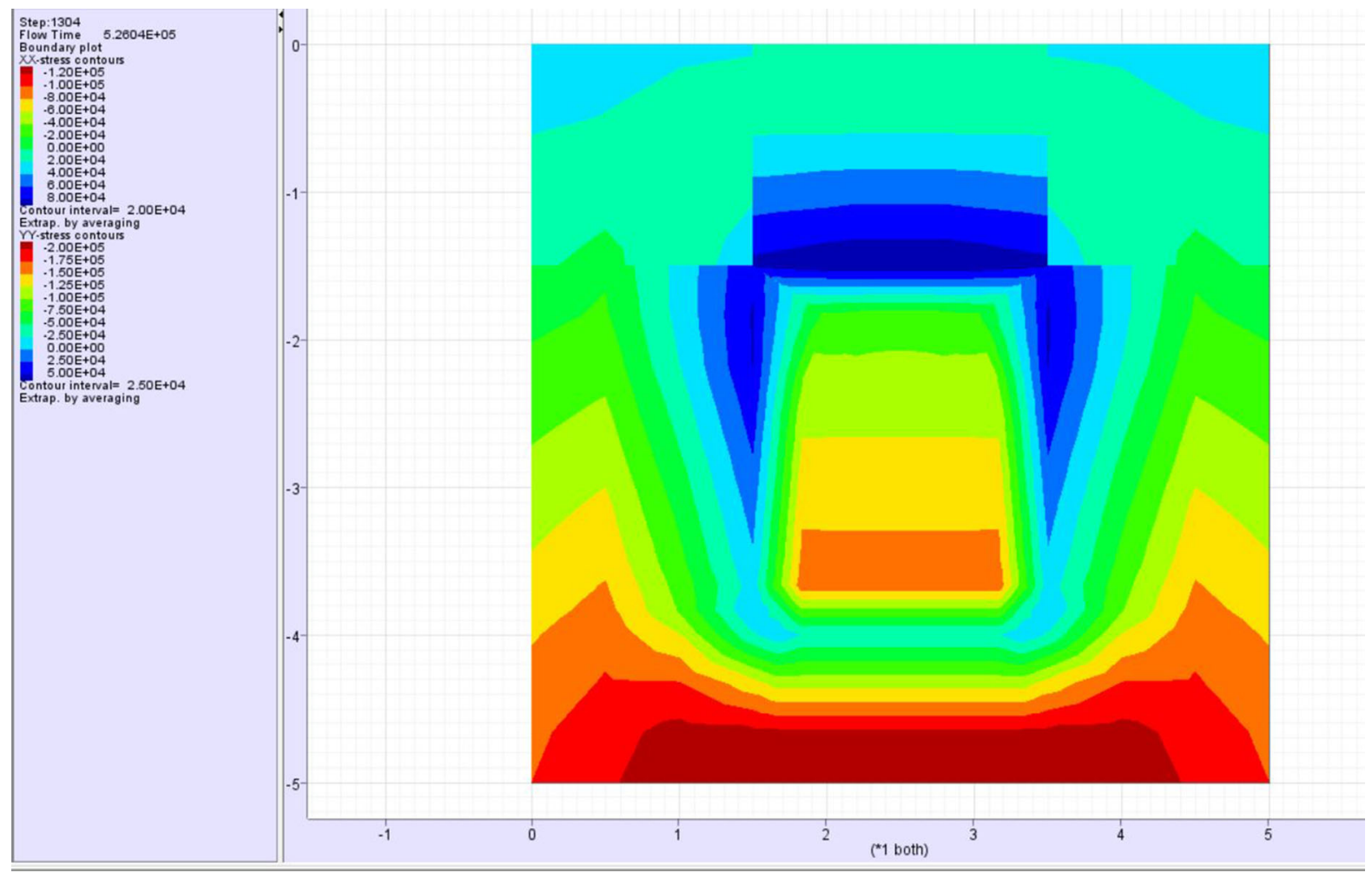

Fig. 9 Shear stress for model before excavating cavern

condition of the strata in its virgin state along with Pore pressure.

The above Fig. 4 model is developed to represent the cavern after excavation with the existence of pore pressure. This model will help in understanding the stresses and displacements after excavating the cavern in the presence of the water-curtaining system (Figs 5 , $6,7,8,9,10,11$ and 12).

\section{Results and Discussion}

\subsection{Dry State}

\subsection{Wet State}

\subsection{Discussion}

From the above graph (Fig. 13) of Sxx stresses, shear stresses in the dry state will slightly increase after the excavation than before the excavation. It is because whenever an excavation is made, stresses will develop 


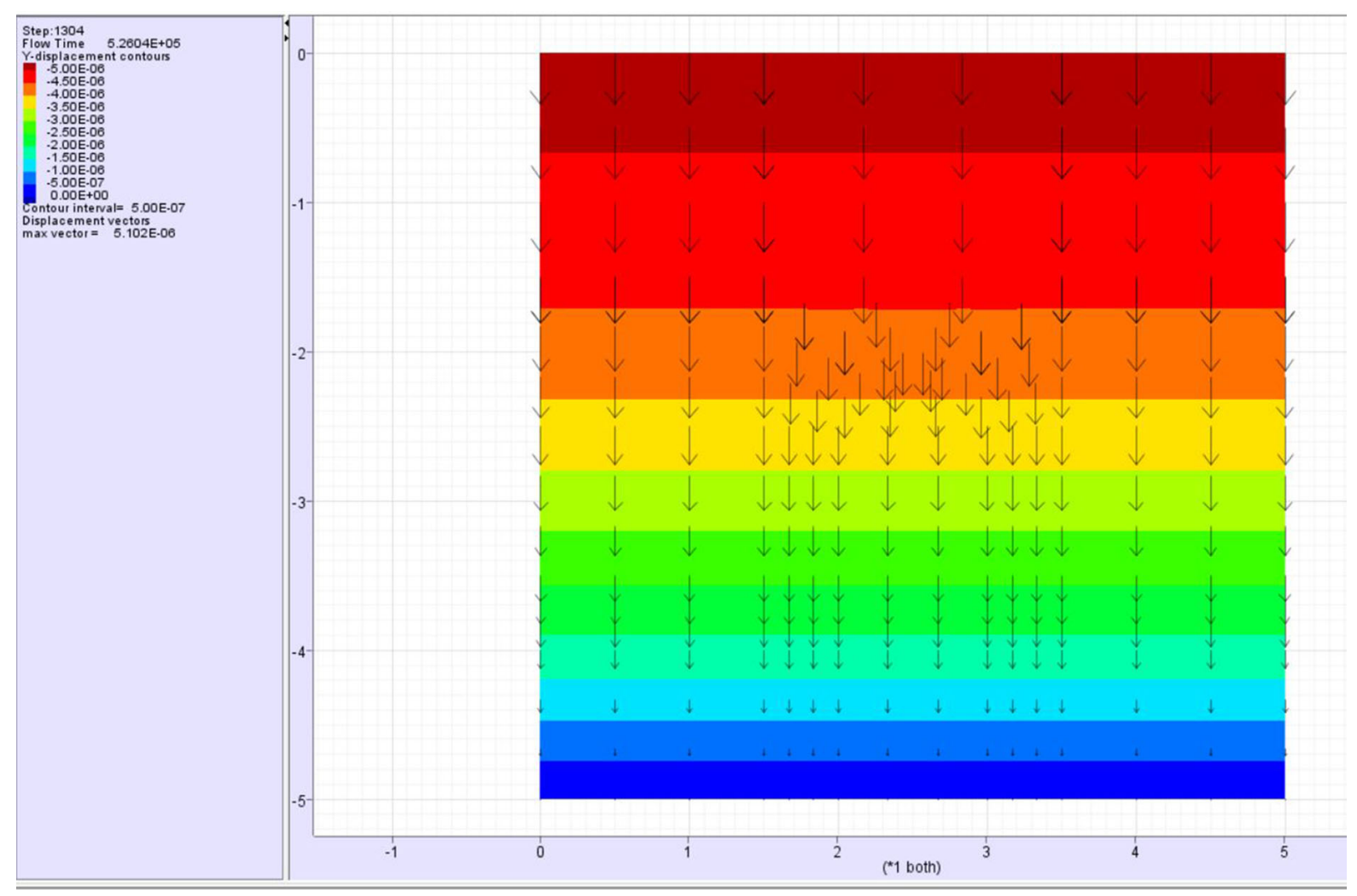

Fig. 10 Y-displacement for model before excavating cavern

around the excavation. Shear stresses in the wet state will slightly increase after excavation when compared to the wet state before excavation. Shear stresses in the wet state are higher than the stresses in the dry state. It is because of the pore pressure applied in the boundaries of the model and the pore pressure around the cavern boundary.

From the above graph (Fig. 14) of Syy stresses, shear stresses in the dry state model will slightly increase after the excavation than before the excavation. It is because whenever an excavation is made, stresses will develop around the excavation. Shear stresses in the wet state model slightly increase after the excavation when compared to the wet state model before the excavation. Shear stresses in the wet state model are higher than the stresses in the dry state model. It is due to the pore pressure applied in the boundaries of the model and the pore pressure around the cavern boundary. It follows a similar trend as the Sxx graph. 


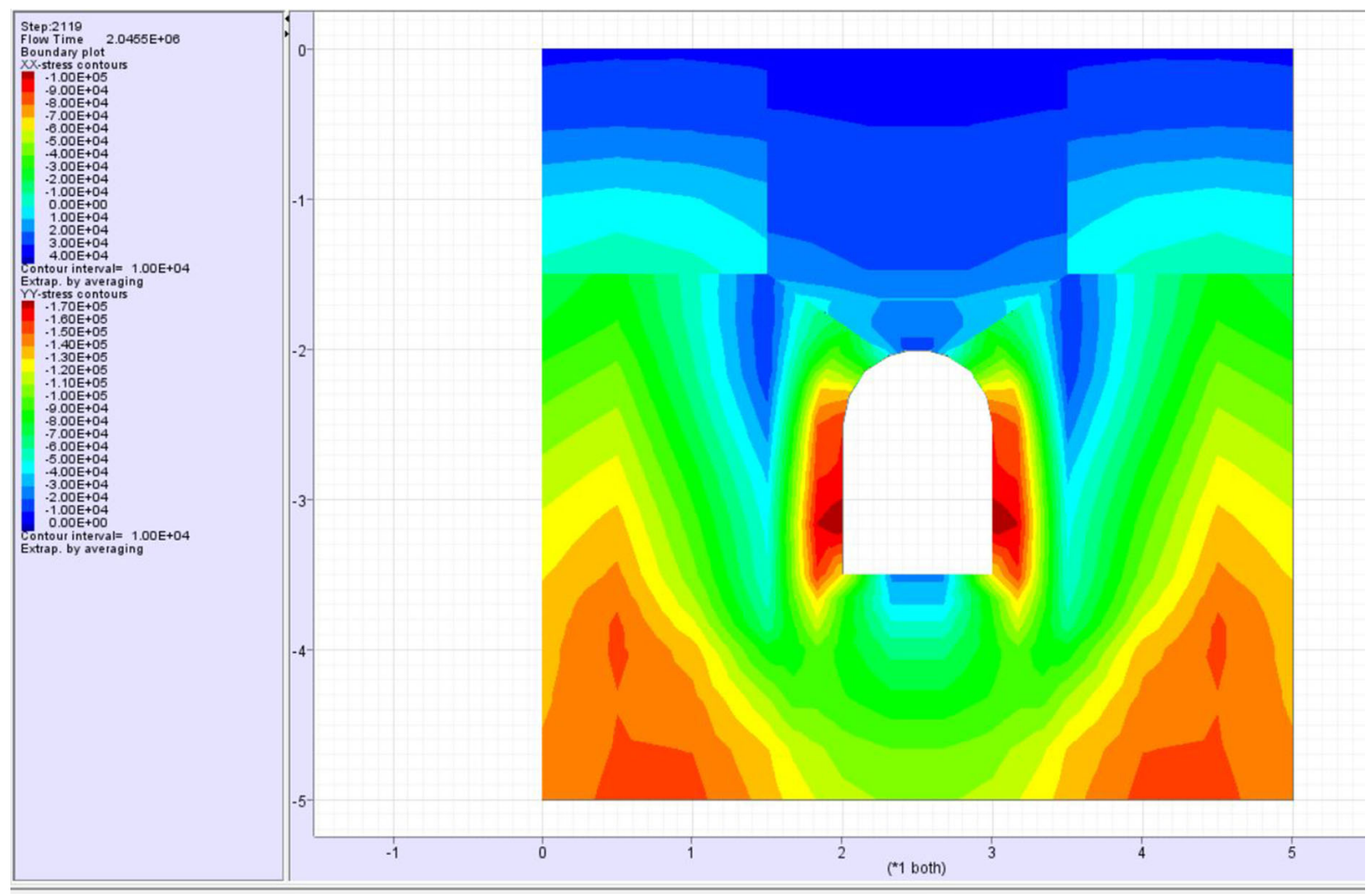

Fig. 11 Shear stress for model after excavating cavern

From the graph (Fig. 15) of displacement, it is observed that there is a constant value before excavation of the cavern structure in both dry and wet state models. When there is an excavation in the dry state model, displacement is increased slightly, compared to the dry state before the excavation. When excavated in the wet state model, there is an increment in the displacement compared to the wet state model before the excavation. After excavation, the displacement in the wet state model is higher than in the dry state model. It explains that the pore pressure around the cavern is causing more displacement than the dry state model. But these displacements will not cause instability in the structure because these will not exceed the permissible limits.

\section{Conclusions}

In the study, stresses and displacement has been analysed very carefully 


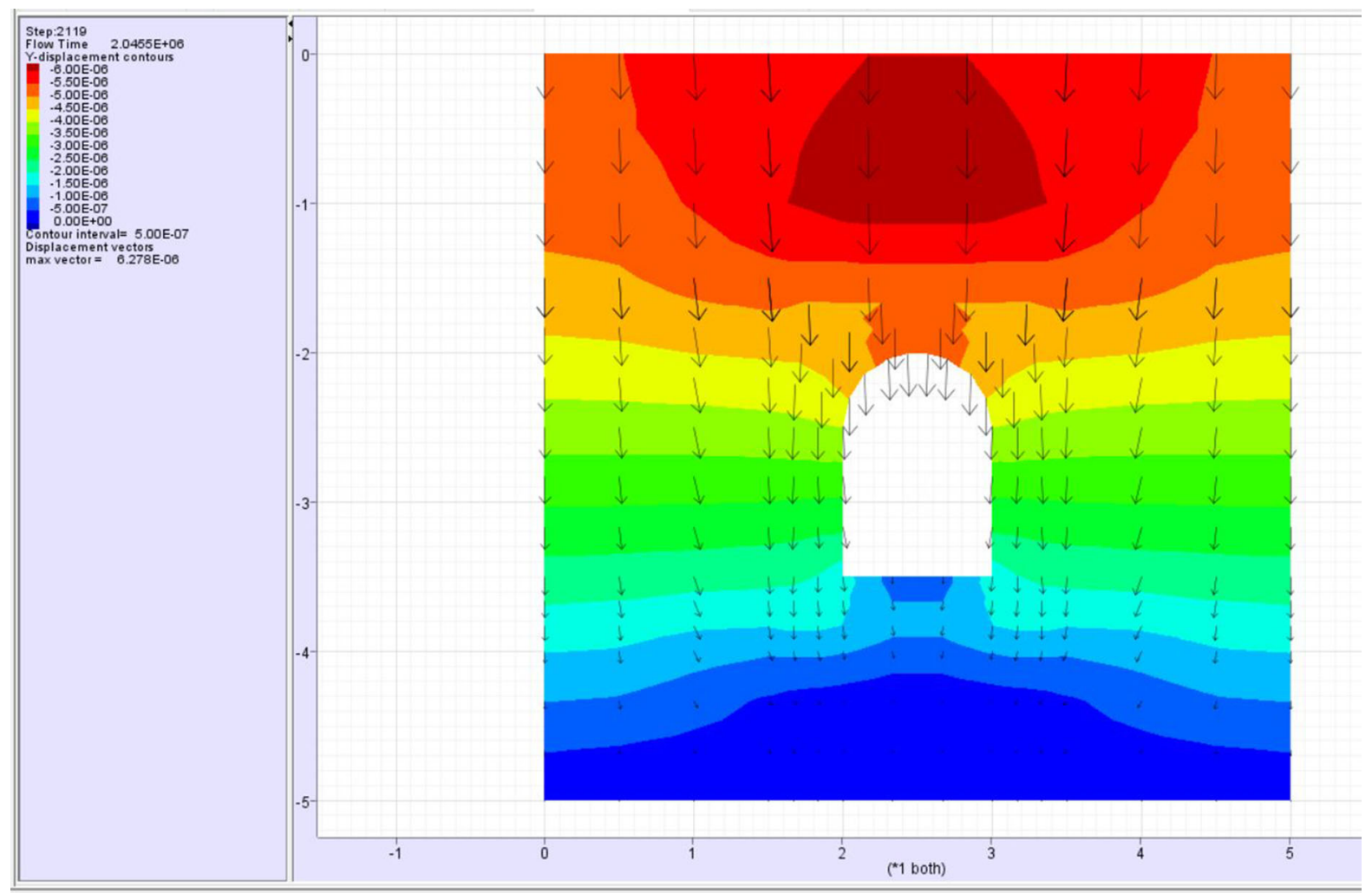

Fig. 12 Y-displacement for model after excavating cavern

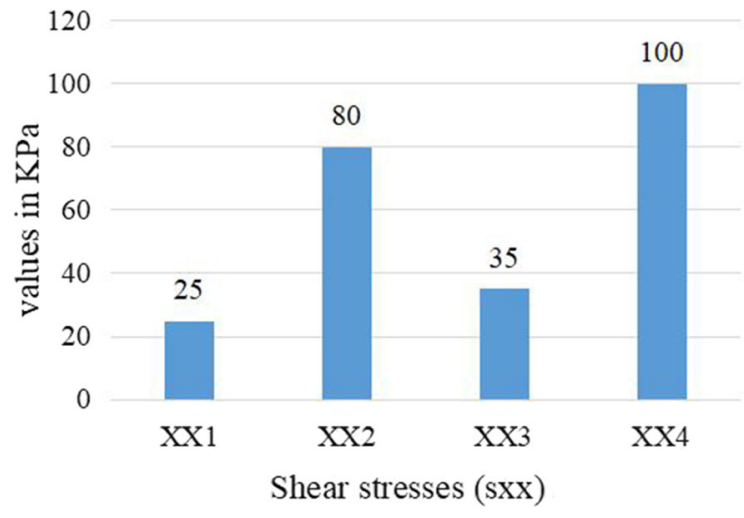

Fig. 13 Comparison of Sxx stresses

1. Shear stresses in the wet state model before and after excavation are higher than the shear stresses in the dry state model before and after excavation.

2. In the wet state model before excavation, the displacement is the same compared to the dry state model which means the presence of pore pressure did not affect the displacement on the ground surface.

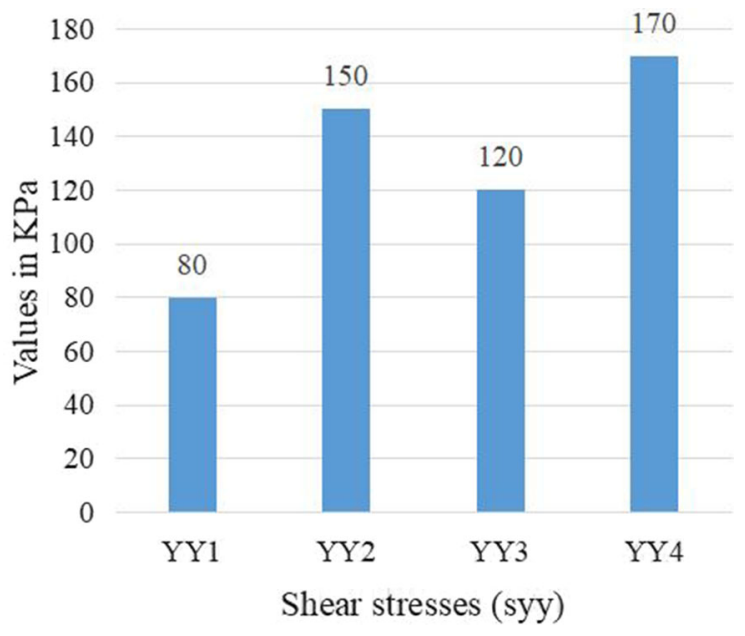

Fig. 14 Comparison of Syy stresses

3. After excavation in the wet state model, the displacement is slightly increased compared to the dry state model which indicates the presence of pore pressure while excavation affects the displacement on the ground surface. 


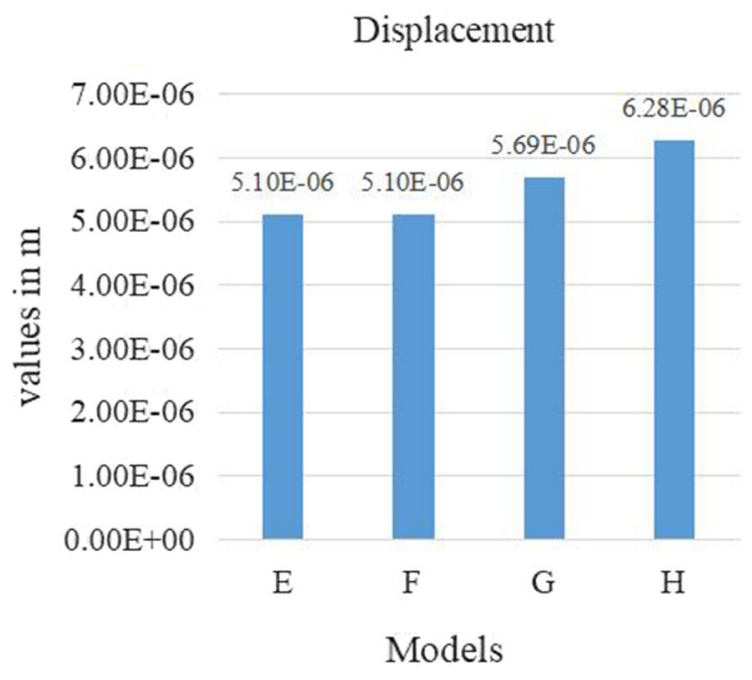

Fig. 15 Comparison of displacement

Thus, the presence of pore pressure is important in keeping the structure stable to counteract the escaping gases from the cavern. The pore pressure is developed through the water curtaining system which includes, water curtaining tunnels, and boreholes at regular intervals around the cavern.

Acknowledgements The authors are thankful to the Head of Department, Mining engineering, and Director VNIT, Nagpur for providing the necessary support and permission to conduct and publish this research work. A special thanks to Nikita Dwivedi who helped in editing and other supports for this study. The views expressed in this paper are those of the authors and not necessarily of the organization they represent. This paper forms a part of the M. Tech dissertation work of the first Author.

\section{References}

Höfer-Öllinger G, Sigl O, Krenn F, Rao BE, Babu VS, Kudtarkar DM, Nizalapur M, Padiyar PS (2014) Underground crude oil strategic storage projects in India. In Proceedings of the World tunnel congress 2014 - Tunnels for a better life. Foz do Iguaçu, Brazil

Li Z, Wang K, Wang A, Liu H (2009) Experimental study of water curtain performance for gas storage in an underground cavern. J Rock Mech Geotech Eng 1(1):89-96

Jie L, Zhao X, Zhang S, Xie L (2018) Analysis of support requirements for underground water-sealed oil storage cavern in China. Tunn Undergr Space Technol 71:36-46

Lee YN, Yun SP, Kim DY, Nam HK (1996) Design and Construction Aspects of Unlined Oil Storage Caverns in Rock. Underground Space in South East Asia 0886-7798(96):00051-00058

Lin F, Ren F, Luan H, Ma G, Chen S (2016) Effectiveness analysis of water-sealing for underground LPG storage. Tunneling Underground Space Technol 51:270-290

Mohanty SK, Sigl O, Krenn F, Höfer-Öllinger G (2018) Underground crude oil storage projects in India. Geomech Tunnell 6:5

Prasanna J, Kumar M, Naithani AK, Rawat DS (2014) Hydroconfinement systems of underground unlined rock caverns for strategic storage of crude oil -A case study. National seminar on innovative practices in rock mechanics, Bengaluru

Wang Z, Li S, Qiao L (2015) Design and test aspects of a water curtain system for underground oil storage caverns in China. Tunn Undergr Space Technol 48(2015):20-34

Publisher's Note Springer Nature remains neutral with regard to jurisdictional claims in published maps and institutional affiliations. 